\title{
ECOWAS' Efforts in Promoting South-South Cooperation Between its Member States and Global South Countries
}

\author{
Esforços da ECOWAS na Promoção da Cooperação Sul-Sul entre seus Estados-Membros e os Países do Sul \\ Global
}

DOI: https://doi.org/10.22456/2178-8839. 113844

Sidnoma Nita Belemsobgo

University of Lagos, Lagos, Nigeria nitabelemsobgo@yahoo.fr

\begin{abstract}
South-South Cooperation (SSC) is an innovative, forthright, and ambitious means to expand collaboration between countries with a similar economic profile. Over the past decade, it straightforwardly imposes within West African states' practices. Indeed, as time passes, many countries have developed significant technical capacities and know-how that they can share. To formalise such sharing of experiences and best practices and raise it to another and higher level, it was essential to hand over this role to a supranational organisation with more tools and experience to coordinate the exchange. In that effect, In West Africa, states leaned towards the Economic Community of West African States (ECOWAS), which gathers 15 member states and which is the main catalyst for promoting exchanges and sharing within the sub-region. The study provides an overview of the South-South partnership promoted by ECOWAS on the economic and social aspects through an exploratory documentary study while providing the levers of development for this partnership. The study's main aim is to assess the importance of SSC for ECOWAS member states sustainable development. The specific objectives are: assess ECOWAS initiatives promoting SSC; provide some cases of success stories of good practices.
\end{abstract}

Keywords: West Africa; ECOWAS; South-South Cooperation;

\section{Resumo}

A Cooperação Sul-Sul (CSS) é um meio inovador, direto e ambicioso para expandir a colaboração entre países de perfil econômico semelhante. Durante a última década, a CSS se impôs diretamente dentro do rol de iniciativas dos Estados da África Ocidental. De fato, com o passar do tempo, muitos países da região desenvolveram capacidades técnicas e know-how significativos que podem compartilhar. Visando formalizar esse compartilhamento de experiências e melhores práticas, elevando-o a patamares cada vez mais significativos, foi essencial entregar esse papel a uma organização supranacion al com ferramentas e experiência para coordenar estes intercâmbios. Nesse sentido, na África Ocidental, os Estados se voltaram para a Comunidade Econômica dos Estados da África Ocidental (ECOWAS), que reúne 15 Estados membros e é o principal catalisador para promover o intercâmbio e o compartilhamento de experiências dentro da sub-região. Este trabalho apresenta uma visão geral da CSS promovida pela ECOWAS a respeito de aspectos econômicos e sociais, através de estudo documental exploratório, fornecendo também as alavancas de desenvolvimento para esta parceria. O principal objetivo deste estudo é avaliar a importância da CSS para o desenvolvimento sustentável dos Estados membros da ECOWAS. Os objetivos específicos são: avaliar as iniciativas da ECOWAS que promovem a CSS; apresentar casos de sucesso de boas práticas.

Palavras-chave: África Ocidental; ECOWAS; Cooperação Sul-Sul; 


\section{Introduction}

The South concept refers to geographic and economic interests, but it has become increasingly associated with international economic dichotomies in recent years. In its broadest sense, South-South Cooperation (SSC) refers to exchanging knowledge and resources among developing countries to identify the most effective steps towards overcoming their developmental challenges. This cooperation frequently occurs at the formal, informal, bilateral, and inter/intraregional levels. In recent decades, a growing number of Southern countries have becomeinvolved in promoting South-South exchanges and responding to various development assistance interventions (GRAY; GILLS, 2016). According to de Renzio and Seifert (2014), these collaborations can take various forms, such as knowledge sharing, training, capacity building programmes, technology transfer, humanitarian assistance, financial and monetary cooperation, technical cooperation, volunteer programmes, etc. It can enable countries to develop joint solutions to common development challenges.

This study assesses the Economic Community of West African States (ECOWAS) efforts' in promoting SSC between its member states and Global South Countries (GSC). This study apprehends SSC in the sense of developing countries working together to find solutions to common development challenges. Concerning ECOWAS, it is an economic integration community established in 1978 , covering $5,114,162 \mathrm{~km} 2$ and about 349 million inhabitants in 2015 . It comprises 15 West African states notably: Benin, Burkina-Faso, Cape Verde, Ivory Coast, Gambia, Ghana, Guinea, Guinea Bissau, Liberia, Mali, Niger, Nigeria, Senegal, Sierra-Leone, and Togo. According to Art 2(1) of its 1978 Treaty, ECOWAS main purpose is to:

promote co-operation and development in all fields of economic activity particularly in the fields of industry, transport, telecommunications, energy, agriculture, natural resources, commerce, monetary and financial questions and in social and cultural matters for the purpose of raising the standard of living of its peoples, of increasing and maintaining economic stability, of fostering closer relations among its members and of contributing to the progress and development of the African continent.

However, as time passes, ECOWAS' main purpose admirably evolved to include other dimensions such as the environmental dimension while acknowledging the necessity of linking economic development to the sustainable use of resources for present and future generations. This change happened in 1993 when the institution was revising its Constitutive Treaty. It acknowledged that economic integration could not be reached if not considering other sectors that might have a direct or indirect impact on this process (ECOWAS, 1993). Thus, with a Treaty almost well tied up (considering the three dimensions of Sustainable Development), ECOWAS focused on facilitating commercial relations between its member states tolift countries' economies up.

Trade is part of the DNA of ECOWAS (KARAKI; VERHAEGHE, 2017) because, since its countries accession to independence (from the years 1960), they were geared tow ards economic reconstruction (ADETULA et al., 2021). Yet, as ECOWAS was trying to pull countries' economies up, many of them faced the eruption of wars and violence. For example, out of the 15 ECOWAS member states, 12 have been affected by armed conflict (BANGURA, 2020; RÖNNBÄCK, 2008). Aside from wars and violence, they are still also dominated and influenced by their colonial pasts. In fact, within ECOWAS, eight countries are former French colonies, five British colonies, and two Portuguese colonies. This dichotomy within the same community influences countries' relations with one another but also their positions on certain policies. For instance, for many years, Nigeria has been reluctant to adopt common money for all countries by fear of the great hold of France on its former colonies. Fortunately, in large part, countries are working to close the different gaps between them through bilateral/multilateral collaborations or negotiations. Paradoxically, despite these moult challenges facing Western African countries, this does not prevent the international community from seeing in this part of Africa lot of potentiality. Taking advantage of this growing interest in the region, ECOWAS has been promoting collaboration between its member states and GSC (MAYAKI, 2017). 
This study, therefore, aims to assess how important is SSC for ECOWAS member states sustainable development. This study fits into the research of the performance of regionalism in view to provide the levers of development of GSC for sustainable development. The specifics objectives of this study are as follows: to assess ECOWAS initiatives promoting SSC; to assess SSC's real potential on ECOWAS member states; to provide some cases of success stories of good practices. In order to achieve these objectives, the study closely looks at the strategies set by ECOWAS promoting SSC. This study addresses the following questions: What are ECOWAS initiatives promoting SSC between its member states and GSC? Is the SSC potential enough exploited in West Africa? How can ECOWAS cooperations with GSC be strengthened? In the spirit of providing answers to the questions mentioned above, some agreements concluded between ECOWAS and some GSC will be reviewed. Arguably, it is considered that the importance of cooperation lies primarily not in its volume but instead in how it transforms populations' living standards and countries' development while increasing the policy options available to partner countries.

This study adopted the "traditional legal method".To answer the research questions, differentlegal sources have been consulted. The method involves enquiries on doctrinal and library-based, including internet sources. This means an extensive review of literature, relevant international laws, scholarly comments, and other relevant materials. These materials obviously relate to ECOWAS activities at the sub-regional and international level, particularly relating to trade promotion and known-how transfer. This analysis is done during the timeframe 1975 (since ECOWAS incep tion) to 2021. The reason is that the study does not want to limit searches about ECOWAS initiatives on SSC. This will allow us to collect all possible information, studies, investigations about ECOWAS dynamism.

However, to the best of our knowledge, no previous study analysed ECOWAS actions in promoting SSC within the West-Africa sub-region and beyond. Although some studies were carried on ECOWAS member states (taken in isolation) collaborations with GSC in some peculiar areas, yet, academic contributions regarding ECOWAS (as sole institution) activities promoting SSC between its member states and GSC are non-existent.

This study is organised as follows. The first section revisits some theoretical proposals on SSC as well as some studies in order to select the direction to give to some key concepts. The second section assesses ECOWAS initiatives promoting SSC. The third section assesses ECOWAS actions in strengthening SSC and highlight some cases of success stories. The fourth and final section discusses ECOWAS commitment, initiatives and actions leading its member states towards the Sustainable Development Goals (SDGs) through the promotion of SSC and provide some recommendations to sustain ECOWAS efforts in that respect.

\section{Explanatory Framework}

Different theoretical frameworks are used to found the arguments of this study. They aim to outline important terms used by scholars, but also the diversity of thoughts developed by many theorists regarding SSC in order to understand the study.

In 61 years of history linked to the development of the countries of the Global South (GS) (1960-2021), we have gone from decolonisation and its hopes to neoliberal globalisation. Therefore, to properly conceive the development concept, it is essential to reconstruct the itinerary of these 61 years (by reviewing some notions like GS) before analysing the contribution of economic social movements in the South that have implemented local development strategies.

The definitions and the views on the concept of GS are numerous and cannot be exhausted. For some, like Bullard, GS is a political concept and political actor (BULLARD, 2012). Taking from the point of view of political concept, it reflects and informs the conditions arising from "global patterns of domination and resistance". Apprehended as a political actor, it represents "all groups with a common experience of exploitation, alienation, and marginalization under neoliberal globalization, both the dominated and the resisters.” However, this perspective and consid eration outtakes GS from the strict notion of "geographical location, economic theory or government policy" (CLAY, 2017). As previously said, there is 
no one strategy for theorising the GS concept. But as time passed, people started to view in the GS, a un ifying identity encompassing developing countries / or third-world countries. This unification has resulted in the formation of the SSC, whose primary goal is to address common challenges such as poverty.

Coming back to the analysis of the contribution of economic social movements in the South that have implementedlocal developmentstrategies, here, two major theories were in vogue in the 1960s and 1970s: Liberal analysis and Marxist analysis.

Rostow's liberal analysis describes economic development as a process consisting of a succession of steps to be followed (more or less) by all countries based on the experience of Northern countries. Here, the concept of development is defined from three elements: urbanisation, industrialisation and the market economy, three engines that would be at the origin of the development of Northern societies from the 19 th century (1830 -1975). But this way of apprehending the development, however, forgets that these engines are not neutral, that they are part of the capitalism. Yet, this industrial and urban capitalism was built based not only on trade and technical progress but also on armed conquests of markets and based on the colonisation of countries of the South. Furthermore, we can notice that in practice, this model was quickly undermined because most of the Southern countries were facing the debt issue. Finally, where some success stories of development were noted, it has been widely demonstrated that the success of these countries was due to the combination of strong state intervention with appropriate choices of integration into the global economy in partnership with local private entrepreneurs.

According to the Marxist analysis of development, Southern countries are in a situation of blockage due to the intervention of the Northern countries in the South at the time of colonisation and, subsequently, through a decisive technological and economic presence, spearheaded by multinational companies. Consequently, the exchange becomes unequal between the nations of the two nations (North-South). Among the main elements of the blockage noted by the Marxist analysis, one has looting of the Third World, then the maintenance of economic dependence after political independence (Colonialism and Imperialism), the deterioration of the terms of the exchange of services and goods (unequal exchange) etc. Some authors, therefore, put forward a theory of dependence of Southern countries on Northern countries (commercial, technological and financial dependence). The problem with this second analysis is that it did not offer any possibility of acting except by considering that revolution could be a game -changer-an attractive perspective for some movements but which was short-lived. Indeed, from the 80's to the 90's, the debate moved rather quickly in another direction because major projects were failing.

The 2000s saw the accentuation of two trends: the economic and diplomatic rise of emerging countries and the breakthrough of the paradigm of "global problems with cooperative solutions". The growing weight of the South, and more particularly of emerging countries, in the world economy was indisputable (based on national GDP, China was the world's largest economy in 2014, while Brazil ranked 6th in 2011).

The actions of Southern countries could be seen as a historical will to build a different model to "the traditional aid paradigm" (Clay, 2017). However, despite this noble ambition, in some cases, Northern countries still manage to involve in these cooperations, sometimes gathering only the least developing countries (as in the case of ECOWAS). For Abdenur and da Fonseca (2013), the involvement of Northern countries in SSC is a way to expand a kind of influence in development cooperation. Nowadays, Realism and Liberalism are two of the most important theories on SSC. Both have their origins in Western capitalist contexts. Among these two theories, Realism has been the most frequently used in SSC. "In an anarchical international system", Realism views international relations as a tool for advancing national interests and increasing state power. Realism reduces allinter-state relations (including SSC) to a competition/strugglefor military and economic power (ignoring a variety of non-material motivating factors such as ideological values and international prestige). Concerning Liberalism theory, here, emphasis is put on the importance of liberalvalues as well as domestic nonstate actors and agendas in developing foreign policy objectives. It promotes international cooperation. 
In addition to these two theories, there is the constructivism. Constructivism asserts that norms and beliefs transcend power politics and material incentives. However, it is more of a method of comprehending the variables and dynamics that shape foreign policy than a theory.

In order to avoid any conflicting situation, we will ground our discussion by considering SSC as an alternative development for developing countries. However, it is important to emphasise that the GS exists and has meaning only in its relations with the global North through the world capitalist system. The studyespouses the idea that national interests are the driving force of development cooperation between Southern states. Given that, by partaking in any cooperation as part of a SSC, GSC are fundamentally motivated by a nationalist interest.

\section{Assessment of ECOWAS initiatives promoting South -South Cooperation}

The main thing that comes to mind when discussing cooperation in terms of development or aid, in general, is North-South Cooperation (i.e., the European Union's Economic Partnership Agreement with ECOWAS). Nonetheless, an increasing number of initiatives are emerging to promote SSC, which could benefit African and GSC through mutual learning and institution building (GOSOVIC, 2016). It is noted that beyond states, regional communities are more and more involved in promoting SSC between their member states and other countries. The latter encompass more resources (technical or financial) that could be a driving force for SSC in Africa. In fact, after the aftermath of their independence, almost all African countries saluted the concept of regional integration. However, due to the failure of national plans to address underdevelopment problems, post-colonial African governments tried solutions on a larger scale (regional and continental level).

This need for African regional integration as a key development strategy was reinforced by the process of globalisation, organised around regional blocs such as the European Union (EU) (one of Africa's sources of inspiration). Regional integration, therefore, appeared as the only means able to solve African countries' common problems and the right platform to develop (with economic integration as a development instrument). Currently, Africa possesses more regional organisations than any other continent. The most notable and the only Regional Economic Community (REC) recognised by the African Union (AU) in West Africa is ECOWAS. However, it is obvious that this initiative of economic integration engaged by the sub-regional community body is hampered by countries similar economic structure, low economic diversification and underdeveloped sub-regional trade of countries. This section assesses ECOWAS legal framework promoting SSC. It also reviews some agreements concluded by ECOWAS with some GSC, such as Brazil and India.

\section{ECOWAS legal framework promoting South-South Relationship}

\section{ECOWAS Revised Treaty}

In 1975 while ECOWAS member states adopted the Community Treaty, no special attention was dedicated to international cooperation. In fact, West African countries were traumatised by the consequence of colonisation, and as a gesture of self-defence, theyfolded on themself. Counting on their same history, sequels and common strength (acting as a leitmotiv for an economic reconstruction), they drew a model of regional integration based on trade or/and economic specialisation. Nevertheless, it is not to say that they did not acknowledge the importance of cooperation with countries outside the Community. Indeed, most colonial cross-border mechanisms were initially maintained after their independence to support the regional integration agenda.

Thus, looking at ECOWAS Constitutive Treaty, one can see that mentions to agreements with third countries are scattered all over the document, and the word third country was mentioned only seven times. The first and second 
mentions were under the section "most favoured nation treatment"; the third, fourth, and fifth mentions under "re exportations of goods and transit facilities"; and the sixth mention under the section "relations with others regional associations and third countries". It was Article 59, which was dealing with the relations with third countries or associations. The above Article was placed in the general and final provisions of the Treaty. Yet, the "relations" mentioned by this Article concerned the event a member state was a member of any other association than ECOWAS.

Fortunately, the revision of the Treaty intervened in 1993 gave another direction to international collaboration. So, as to depart from the scattered and uncoordinated plans and ambitions (as shown the scattering reference of international cooperation in ECOWAS Constitutive Treaty), the Revised ECOWAS Treaty organised international cooperation. Indeed, the Treaty dedicates a whole chapter to cooperation agreements. Here, a special position is devoted to the relation between the Community and third countries or international organisations. Indeed, Chapter XX which comprises one Article (Article 83), focuses on cooperation agreements. The above Article stipulates that:

The Community may conclude co-operation agreements with third countries [...] Co-operation agreements to be concluded in accordance with the provisions of paragraphs 1and 2 of this Article shall be subject to prior approval by the Council upon the proposal of the Executive Secretary.

In 2006, ECOWAS Authority of Heads of State and Government transformed the Executive Secretariat into a Commission. Following this transformation, a new Protocol (Supplementary Protocol A/SP.1/06/06 amending the Revised Treaty) is adopted the same year to revise those obsolete provisions or words in the Revised Treaty. The new Paragraph 3 of Article 83, which still deals with cooperation agreements, is now formulated as follow: "Cooperation agreements to be concluded in accordance with the provisions of paragraphs 1and 2 of Article 83 of the Revised Treaty shallbe concluded by the President of the Commission who shall fulfill the conditions stipulated under new Article 79(2) above”.

Based on the provisions of the above Article, the president of ECOWAS Commission has mandate to negotiate any accord of cooperation that might benefit member states. As such, several agreements or cooperations have been concluded in the past by the institution, mainly in the trade, education, agriculture (biotechnology), mining, health, and military sectors. Furthermore, aside from Article 83, Article 79 also allows the Community to cooperate with other regional communities. Given that, many cooperation agreements exist between ECOWAS and other institutions such as the WAEMU (West African Economic Monetary Union), the EU, the Permanent Interstate Committee for drought control in the Sahel (CILSS), etc.

Although ECOWAS Revised Treaty grants an important place to SSC, other legal instruments also adopted by the community address the importance of the collaboration between Southern countries and ECOWAS member states more extensively.

\section{Others Legal Instruments}

Within ECOWAS legal framework, in addition to the Revised Treaty, some other legal instruments (either deriving from its primary or secondary source) highlight the importance for the community to cooperate with third countries, mostly those from the GS, for a sharing of experience and good practices. As other legal instruments, there are Regulation C/REG14/06/13 on ECOWAS Small-scale Hydropower Program, ECOWAS Regional Research Policy (2012), the Directive A/DIR.1/06/12 on Science, Technology and Innovation (2012) etc. For instance, Article 4 of the Regulation on ECOWAS Small-scale Hydropower Program stipulates that the United Nations Industrial Development Organization (UNIDO) shall bring technical expertise and facilitate South-South and North-South Cooperation. As for ECOWAS Regional Research Policy (in its annexes), it highly stresses the need to "strengthen partnership with other stakeholders in the South". Article 9 of the Directive on Science, Technology and Innovation notes that: "In order to ensure the promotion 
of STI and the effective implementation of this Directive, Member States may conclude agreements with ECOWAS nonmember States and other scientific organizations $[. .$.$] ”.$

It is obvious that ECOWAS acknowledges the importance of partnering with other countries to address West Africa's various challenges. Although provisions relating to SSC are scattered and not gathered in one and sole document, it is laudable to appreciate the community's efforts. Indeed, this is a paradigm shift because the commu nity recognises that SSC could also be an asset for countries with almost similar realities and challenges. Thus, it is not relying anymore exclusivelyon North-South cooperation, but it also opens itself to new ways of collaborations and perspectives.

Nevertheless, this study considers that beyond the adoption of some dispositions on SSC, ECOWAS actions in adopting binding and non-binding norms still remain shy. Most of the time, the communitymaintains close relations with Global North countries like Germany or the EU. This is shown by the high number of agreements it has concluded. Non exhaustively, we have, for instance: the signing of a $€ 25$ million funding agreement with Germany to support health projects in West Africa (2 December 2016); the Development Cooperation Agreement with Germany to strengthen the Community's integration programmes (signed on 16 November 2017); the Development Cooperation Agreement between ECOWAS and Germany covering sectors such as cooperation on trade liberalisation, strategie s to deal with irregular migration and technical cooperation on organisational development (10 October 2019) etc. Regarding the EU, the formalisation of partnership was deeper. For instance, during ECOWAS Conference of Heads of State and Government thirty-ninth ordinary session held in 2011 in Abuja, in the final communique, the Conference expressed its deep concern at the deadlock in the Economic Partnership Agreement (EPA) negotiations resulting from the persistent differences between the EU and West Africa. Given that, they were willing to offer the EU an opening of the market up to $70 \%$ over 20 to 25 years (ECOWAS Official Journal Volume 58).

To strengthen cooperation with GSC and act together in international negotiations, a concrete will of partnership must be established like the one with the EU. Thus, ECOWAS needs to legislate more in that direction (adoption of provisions promoting partnership in general or in isolation) and also be bold in terms of openness.

\section{Agreements between ECOWAS and some Global South Countries}

As time passes, ECOWAShas diversified its economic partnersworldwide, particularlywith GSC, by establishing closed cooperation with those countries. Among those countries, we have Brazil and India. These agreements concluded with the two countries are some examples of SSC that could be seen as "pragmatic and efficient" actions reflecting a gradual decrease of influence in West Africa of the "major powers" that were until recently considered the main "allies” of the African continent.

Brazil

Scholars from Latin American (mostly from Brazil and Argentina) conceive that there exists a Latin American theoretical approach that aims to provide answers to regional problems. For Bernal-Meza (2016), "it is not absurd to construct a theoretical, methodological or conceptual framework to support external policies whose purpose is not the struggle for world power, but to overcome underdevelopment and dependence". From 1949 to the late 1970s, three different waves of thoughts/ theories have succeeded in reflecting Latin American thoughts to regional issues (development theory, dependency theory, and autonomy theory). Following these three theories, the 21st century witnessed a new trend of thinkers called the "post-autonomists". For instance, "Tullo Vigevani and Gabriel Cepaluni (2007) formulated the concept of "autonomy through diversification” to explain Lula Da Silva's foreign policy (2003 2011)” (LECHINI; DUSSORT, 2020). 
Indeed, the former Brazilian president Luiz Ignacio Lula Da Silva is a personality well-known for having played a key role in Brazilian presence in Africa. For Abdenur et al. (2013), Lula Da Silva "viewed an increase in diplomatic representations not only as a way to strengthen relations with the Global South but also as a way to forge a more autonomous foreign policy”. Nowadays, "Brazil has one of the largest diplomatic networks in the world, with Embassies and Consulates in over 150 countries" (BRAZIL AFRICA INSTITUTE, 2021). Some others authors, such as Cabral et al. (2013), De Renzio and Seifert (2014), Leite (2015), also shared Abdenur etal. point of view. They consider that during Lula's presidency, Africa-Brazil relationship intensified. Indeed, the former president viewed Africa as a potential partner with which there were many affinities. Aside from the affinities, in 2004, during a tour in four South African countries, Lula pointed out that: "Brazilian society was built on the work, the sweat and the blood of Africans [...]. For that reason, Brazil is in debt to Africa [...] a debt which the country intends to repay by strengthening its solidarity and cooperation" (Harsch, 2004). These "smooth-spoken" words of Lula did not fall on deaf ears. ECOWAS, which was in a dynamic of exploring and exploiting new markets while trying to diversify countries' economies, took the opportunity by showing its willingness to collaborate with Brazil.

As early as 2008 (during ECOWAS Council of Ministers sixtieth ordinary session), when Regulation C/REG.5/05/08 was adopting ECOWAS Action Plan for the Development of Biotechnology and Biosafety, it acknowledged that in order to maximise the benefits of modern biotechnology, ECOWAS should not only promote the adoption of biotechnology products, but it shall follow the example of countries like Brazil (ECOWAS Official Journal Volume 53). Thus, Brazil was already holding an important place in ECOWAS policy as one of the most important partners to achieve the aim of the Plan.

In September 2010, during ECOWAS Heads of State and Government summit held in Cabo Verde, where Lula attended, the two parties (ECOWAS and Brazil) advocated for greater cooperation. One year later this meeting (2011), the commitments were materialised by the place granted to Brazil in ECOWAS exportations. Indeed, it was ECOWAS third main export partner after USA and India (ECOWAS Commission Regional EUROTRACE Base). In 2016, it was the fourth main ECOWAS' exportation partner with US\$ 6,633 million (ECOWAS Commission Regional EUROTRACE Base). In fact, in ECOWAS curricula, Brazil is one of its main partners and even is in the top ten partners' countries. In order to strengthen more Brazil and ECOWAS ties, recently, in October 2019, the president of the ECOWAS Commission received Brazil's ambassador letter of credence, who was accredited to ECOWAS. After presenting ECOWAS' letter of acceptance in reciprocity, it was about strengthening the cooperation between them one more time.

Concerning the domain of cooperation, according to Abdenur (2013), "Over the past decade, Brazil has dramatically diversified its relations with Africa.” As far as ECOWAS sub-region is concerned, we have, for instance, the health sector (15 medical professionals Cabo Verde are trained in Brazil to fight malaria); aeronautical sector and the cultural sector (ECOWAS supported the 4th edition of the FEAFRO Trade Fair held in Benin in 2018 promoting AfroBrazilian culture) (ECOWAS, 2017). ECOWAS and Brazil have also been trading a lot. The bilateral trade between Brazil and ECOWAS from 2016 to 2020 is depicted in the table below. It lists the top 10 main products of the year 2018 subject to export. 
Table 1 - 10 main Export products from ECOWAS to Brazil - 2018/2020

\begin{tabular}{|l|l|l|l|l|}
\hline \multirow{2}{*}{ Number } & \multicolumn{1}{|c|}{ Productlabel } & \multicolumn{2}{c|}{$\begin{array}{c}\text { Economic Community of West African } \\
\text { States (ECOWAS)'s exports to Brazil }\end{array}$} \\
\cline { 3 - 5 } & & Value in 2018 & Value in 2019 & Value in 2020 \\
\hline 01 & $\begin{array}{l}\text { Mineral fuels, mineral oils and products of their distillation; } \\
\text { bituminous substances; mineral... }\end{array}$ & $1,566,360$ & 742,517 & 39,712 \\
\hline 02 & Cocoa and cocoa preparations & 200,816 & 99,894 & 0 \\
\hline 03 & Fertilisers & 136,177 & 101,437 & 105,502 \\
\hline 04 & Rubber and articles thereof & 26,030 & 27,541 & 0 \\
\hline 05 & Edible fruit and nuts; peel of citrus fruit or melons & 11,625 & 6,974 & 0 \\
\hline 06 & Ores, slag and ash & 4,647 & 10,330 & 643 \\
\hline 07 & Plastics and articles thereof & 8,033 & 8,024 & 0 \\
\hline 09 & $\begin{array}{l}\text { Natural or cultured pearls, precious or semi-precious stones, } \\
\text { precious metals, metals clad... }\end{array}$ & 1,978 & 7,383 & 0 \\
\hline 10 & Aircraft, spacecraft, and parts thereof & 1,138 & 14,412 & 0 \\
\hline
\end{tabular}

Unit: US Dollar thousand

Source: Author's computations with data from ECOWAS Trade Information System (ECOTIS), (2021).

As shown from the table, in 2018, the mains products subjected to export were mainly from Mineral resources, Aeronautical and agro-food sectors. Deeper collaboration between ECOWAS and Brazil in the style of the one of EPA concluded between ECOWAS and the EU could fuel stronger and deeper cooperation between them. In that regard, "Brazil urgently needs to reposition Africa in trade policy and give a new step, by complementing tra de diplomacy for Africa as a whole with closer ties focusing on specific partners [...]” (Brazil Africa Institute, 2021). This need is even more imperative because, with the advent of the COVID 19 in 2019, the world acknowledged how interdependent countrie s are. This feeling is still stronger in Southern countries, which realised that solidary between southern countries are important.

India

Historically, Indian investments in Africa, both public and private, have been limited to Eastern and Southern African countries due to geographical proximity and a large Indian diaspora in these regions (Mishra, 2019). Fortunately, Indian investments in Africa have significantly increased over the last ten years in terms of geography and coverage of different sectors. Exploring new countries as potential partners was deemed necessary for India in order to improve its economy. Moreover, the soaring rise of China as an important market and a partner for African countries also motivated India to curry favour with other African countries. These are some reasons that led India to start partnering with other regions of Africa, such as West Africa, with Nigeria as a potential big market.

Nowadays, like Brazil, India is an important economic partner for ECOWAS. To institutionalise its partnership with India, in 2003, through Decision A/DEC.5/01/03 adopting a plan of action to facilitate the sub -regional integration of education objectives for sustainable development, ECOWAS was charging "India, Nigeria, UNESCO, and BREDA of the project on teacher training through open and distance education" (ECOWAS Official Journal Volume 42). Further, the same decision was charging “India, Ghana, ILO, JICA, UNESCO, the World Bank of the project on vocational training” (ECOWAS Official Journal Volume 42). Another examplebut not the last is the ECOWAS Action Plan for the Development 
of Biotechnology and Biosafety. In fact, in the plan, India was associated in five different projects (ECOWAS Official Journal Volume 53).

On the other side, India shows its willingness to help ECOWAS member states promote trade and investment. For instance, the EXIM Bank (Export-Import Bank of India) uses to supportECOWAS (GULATI; DAS, 2020). In fact, in 2018, EXIM Bank had supported Lines of Credit (LOC) valued at US\$2,862.5 million, covering 15 countries, and ECOWAS Bank for Investment and Development (EBID) (GULATI; DAS, 2020). More recently, in February 2021, it signed the last LOC of a series of five amounting to $\$ 15$ million with Sierra Leone. In addition, the Bank has also signed a Memorandum of Understandings and Memorandum of Cooperation through the Government of India with governments in West Africa to promote trade and investment (MISHRA, 2019). Undoubtedly, West Africa emerges as an essential partner for India, both as an export market and an import source.

In 2016 India was ECOWAS' first export partner for \$16,143 million and the third import partner with US\$ 5,293 million for imports (ECOWAS Commission Regional EUROTRACE Base). In 2018, more than 14 million US dollars were assessed on ECOWAS exports to India. The table belowlists the top 10 main products of the year 2018 subject to export.

Table 2 - 10 main Export products from ECOWAS to India - 2018/2020

\begin{tabular}{|c|c|c|c|c|}
\hline \multirow[t]{2}{*}{ Number } & \multirow[t]{2}{*}{ Productlabel } & \multicolumn{3}{|c|}{$\begin{array}{l}\text { Economic Community of West African States } \\
\text { (ECOWAS)'s exports to India }\end{array}$} \\
\hline & & Value in 2018 & Value in 2019 & Value in 2020 \\
\hline 01 & $\begin{array}{l}\text { Mineral fuels, mineral oils and products of their distillation; } \\
\text { bituminous substances; mineral... }\end{array}$ & $8,841,154$ & $8,650,941$ & $4,954,982$ \\
\hline 02 & $\begin{array}{l}\text { Natural or cultured pearls, precious or semi-precious stones, } \\
\text { precious metals, metals clad... }\end{array}$ & $3,691,008$ & $2,530,685$ & 0 \\
\hline 03 & Edible fruit and nuts; peel of citrus fruit or melons & 955,556 & 598,425 & 38,773 \\
\hline 04 & $\begin{array}{l}\text { Inorganic chemicals; organic or inorganic compounds of } \\
\text { precious metals, of rare-earth metals,... }\end{array}$ & 273,353 & 407,744 & 262,984 \\
\hline 05 & Wood and articles of wood; wood charcoal & 72,591 & 62,306 & 0 \\
\hline 06 & Ores, slag and ash & 72,212 & 120,723 & 4,562 \\
\hline 07 & $\begin{array}{l}\text { Salt; sulphur; earths and stone; plastering materials, lime and } \\
\text { cement }\end{array}$ & 57,318 & 58,087 & 28 \\
\hline 08 & $\begin{array}{l}\text { Electrical machinery and equipment and parts thereof; sound } \\
\text { recorders and reproducers, television... }\end{array}$ & 55,865 & 8,774 & 56 \\
\hline 09 & Rubber and articles thereof & 47,366 & 38,225 & 355 \\
\hline 10 & $\begin{array}{l}\text { Oil seeds and oleaginous fruits; miscellaneous grains, seeds and } \\
\text { fruit; industrial or medicinal... }\end{array}$ & 38,443 & 77,725 & 44,458 \\
\hline
\end{tabular}

Unit: US Dollar thousand

Source: Author's computations with data from ECOWAS Trade Information System (ECOTIS), (2021).

Unambiguously, India and ECOWAS can play a significant role in helping each other's economies with their experience and expertise. Nevertheless, concrete initiatives and policy changes need to ad dress the current infrastructure 
gap to reach India-West Africa's investment potential. West African counties must also look to avail the opportunities presented by India's Duty-Free Tariff Preference (DFTP) scheme to increase their exports to India. Due to the multiple interventions of India in West Africa and their tight collaborations, India -West Africa partnership could be a perfect tieup between resources and talented people of West Africa with Indian skills and expertise. As stipulated by ECOWAS Industrial Policy of 2010, "West Africa would benefit greatly from increasing cooperation with the rest of Africa and other parts of the southern hemisphere" (ECOWAS Official Journal Volume 57). In that sense, it is essential for ECOWAS to keep collaborating with India.

\section{Strengthening South-South Cooperation and Success Stories}

This study acknowledges that the potential for SSC in Sub-Saharan Africa remains largely untapped. Nowadays, many West African countries are experiencing tremendous economic growth (Nigeria, Ghana, Burkina, etc.), and their increased wealth could provide more resources for SSC, which could help strengthen the economic, cultural, and social advances for other GSC countries. Indeed, some countries like Nigeria and Ghana have become important markets and emerge as significant investors or suppliers of different kinds of goods and services (HOLLINGER; STAATZ,2015). As such, Eregha (2015) notes that the inflow of foreign direct investment in the ECOWAS sub-region clearly showed an increase. Yet, many of these emerging economies are a bit reluctant to publicise their exact foreign aid figures, or the exact use of the money, or the real inflow. This is because publication may have repercussions in connection to these countries' cooperation arrangements with other countries and draw civil society and local population attention (HACKENESCH; JANUS, 2013). This complaint of non-publication of data or non-transparency addressed to some ECOWAS countries are also directed towards ECOWAS institution.

Consequently, it is sometimes difficult to assess SSC's real potential and impact on member states (LAL, 2019). This study considers that there is no accountability and transparency in the absence of publication and participation. Thus, regular public disclosures of programs, finances, and human resources allocated to SSC would enhance transparency and accountability. It would also improve the potential of the SSC, which remains insufficiently exploited within ECOWAS. Furthermore, face to this situation of data precarity, one couldbe tempted to conclude that the impact of SSC on the ground (West Africa) is negligible. This would be a big mistake because for the agreements already concluded and whose data and results are recorded indicate evident signs that these cooperations are conducive for ECOWAS countries' sustainable development.

The already cooperations engaged by ECOWAS have shown some important results for countries both on the social and economic level, encouraging and comforting us that West Africa could benefit more by exploring more SSC. For instance, the Indian Technical and Economic Program (ITEC) has provided Ghana, Senegal, Burkina Fa so, and Mali (four ECOWAS countries) equipment and expertise for enhancing agricultural productivity and generated goodwill for India among African countries (VAZQUEZ; LUCEY, 2016). It is also the case of the cooperation between Brazil, Burkina Faso, Benin, Chad, and Mali concerning the Cotton.

Concerning specifically Brazil, "Brazil is a source of world-leading expertise across a range of areas of great relevance to developing countries' development processes - most notably agricultural research, health and social protection” Cabral et al. (2013). In fact, since 2013, the Brazilian government, particularlythe Brazilian Cooperation Agency $(\mathrm{ABC})$, has invested time and resources in strengthening the management of its South-South technical cooperation (FAO, 2015). As time passes, Brazilian investment in agriculture in West Africa (notably in ECOWAS member states) has considerably increased. Brazil has been assisting Africa in increasing its food and energy security and bolstering its economic independence through trade and investment, cooperation, and technology sharing. In this context, EMBRAPA, the Brazilian Enterprise for Agricultural Research, has been spreading Brazilian "know -how" and technology across Africa in several projects (ABDENUR, 2015; CABRAL et al., 2013). 
The study considers that cooperations between ECOWAS and other GSC need to be strengthened, and this is more vital because, since the beginning of COVID 19, all activities and projects of cooperation between countries have been disrupted.

\section{Discussion and Recommendations}

ECOWAS promotes regional integration to establish more reliable, liberal, and prosperous state systems internationally and security and economic development. In this process, the regional community has also been militating for greater collaborations between its member states and others countries. For instance, in its Industrial Policy, it was acknowledged that: "ECOWAS' South-South cooperation will be more cost-effective when West African businesses and entrepreneurs will have access to a wide range of technological choices, establish links with local universities and managing research-development projects resulting from this collaboration” (ECOWAS Official Journal Volume 57). Without any doubt, the growing relationship between ECOWAS and other Southern partners could support the development of productive capacity and thus contribute to the achievement of many Sustainable Development Goals (SDGs). However, this study considers that this potential can only be achieved if countries become more proactive in the process and use their leverage with Southern partners to persuade them to strike a balance between their commercial or strategic interests and the region's development needs. This goes to some extent in the direction of SSC vie wed by Realism theory scholars.

In addition, this study considers that SSC does not constitute an alternative to North -South cooperation but just complements it. Insofar as SSC lacks the overtones of cultural, political, and economic supremacy sometimes as sociated with traditional North to South transfers, ECOWAS countries might benefit significantly from such cooperation in various ways. Given that, it would be of benefit of ECOWAS to exploit more the potentiality of SSC. To facilitate such a process, regional solidarity in the spirit of South-South initiatives promotions should generally develop on their own, through the accumulation of shared experiences, increased appreciation of Community benefits, or a progressively clearer perception of the common interest. In this same vein, it would be necessary to put in place national mechanisms designed to propagate the virtues of regional integration and promote a better understanding of the contribution that regional cooperation can make in pursuing national development aspirations. Otherwise, ECOWAS initiatives and actions tending to promote cooperation with other GSC will not have a real impact and might enrich individuals' needs.

As we look at the benefits of the SSC, we must keep gender equality in mind. In the context of ECOWAS, the institution shall make the role of women more visible. Also, this shall not prevent the sub -region women from taking the lead in articulating the challenges theyface and the assistance they require across the value chain in order to become more efficient and prosperous in their endeavours (this is because they uniquely and differentially undergo the impact of poverty). One area that might yield collaboration between ECOWAS member states women and other GSC, concerns, for instance, the agricultural sector. In fact, due to the gender-based division of labour, women and men have different knowledge of plants and agricultural techniques. Cooperation agreements promoting the exchange of women knowledge on biodiversity could be, for example, potential solutions to address climate change. As noted by Eregha, taking a look at the international community's participation in SSC, one can see that more resources are available for developing countries to pursue their national development plans (EREGHA, 2015). Which is quite interesting for ECOWAS countries.

Although resources exist yet, many consider that most West African countries are not ready to meet the challenges linked with SSC, such as the constantly changing technological environment and the required skills to innovate, adapt, diversify, etc. To some extent, these considerations are justified because countries must have clear national policies and institutional frameworks for SSC to operate effectively. It is crucial for ECOWAS countries to be bold leaders, which through SSC find and identify development models that fit them. This study, therefore, considers that the process could 
be accelerated through an awareness-raising effort to place national interests within a regional framework or advocate regional policies and mechanisms that can help satisfy those interests.

The study provides these recommendations in order to sustain ECOWAS efforts in promoting SSC. To establish more substantial value chains in the global South, it is also essential to drive an approach that increases South-South trade and investment to facilitate effective development. A 2012 publication by the International Trade Centre and the Research and Information System for Developing Countries described various strategie s supporting this initiative (MOHANTY; DASH, 2012). One of the most significant suggestions concerning developing strong value chains would be targeting complementary opportunities available in the Global North and the Global South.

It is also crucial for ECOWAS to establish a watch cell to ensure the coordination of national policies and regulations related to SSC and their well-monitoring. This will further help assess the practical effect of SSC cooperation on its member states compared to North-South cooperation. It can also be coupled to the watch cell, a monitoring and evaluation (M\&E) framework that will support the assessment of the impact of such cooperations.

Aside from the watch cell, ECOWAS institution shall make available documents, agreements of cooperation between it and other GSC. In fact, ECOWAS is well-known for not sharing information with the general public. Data collection requires most ECOWAS citizens or researchers to travel to Abuja (Nigeria capital) for that purpose. This is really ridiculous given the new technologies that exist in this 21st century. Moreover, the data collection process is so cumbersome that it might discourage many (introduction of request letter at many levels, interviews, waiting for approval or rejection etc.). It might benefit the institution and its member states to publicise those legislations and agreements with other countries for a general following up of projects and programmes. To sum up, the study posits that RECs like ECOWAS could be the cornerstones to unlock the potential of SSC for member states, yet, leaders need to express a real political will, be transparent and adopt common values.

\section{Conclusion}

ECOWAS is the only regional community recognised by the AU in West Africa. It is also the most advanced community (in terms of integration) among the eight RECs recognised by the AU. The study aimed to answer the following questions: What are ECOWAS initiatives promoting SSC between its member states and GSC? Is the SSC potential enough exploited in West Africa? How can ECOWAS cooperations with GSC be strengthened? Based on an analysis of the legal provisions adopted by ECOWAS, or its practice (conclusion of memorandum) or of the literature on African regional communities, we have tried to answer the different questions.

From our findings, it comes out that although ECOWAS adopted Policies, Recommendations, Decisions promoting and acknowledging the importance of collaborating with other GSC such as Brazil, India, Venezuela etc., to solve common problems (industrial, biotechnological), the potential of SSC remains under-exploited by the community. In fact, although true, the currentSSC engaged by ECOWAS promotes closer technical and economic cooperation between ECOWAS (as a sole institution) and other countries or communities, or between ECOWAS member states and other countries from the global South, the community needs more zeal.

The study considers that SSC is a vital force that could pull ECOWAS countries out of their economic slump by opening new opportunities if well-monitored. These cooperations pave the way to better sharing best practices, allowing countries to diversify and expand their development options and economic links. It is true that since its inception, ECOWAS countries have made significant progress in the process of regional integration; however, the study considers that with such a diversity of new partners (from the Global North and the Global South), it is an opportunity for countries to explore more new horizons.

In order to strengthen cooperation between ECOWAS and other GSC, the study recommends that ECOWAS adopts a strategy that enhances South-South trade and investment within the sub-region. It is also important that 
ECOWAS establish a watch cell to coordinate national policies and regulations related to SSC, make available documents, agreements of cooperations between it and other GSC, etc.

\section{References}

ABDENUR, Adriana Erthal. Organisation and Politics in South-South Cooperation: Brazil's Technical Cooperation in Africa. Global Society, v. 29, n. 3, p. 321-338, 2015. Disponível em:https://doi.org/10.1080/13600826.2015.1033384. Acesso at: 6 Aug. 2021.

ABDENUR, Adriana Erthal; DE SOUZA NETO, Danilo Marcondes. South-South cooperation and democracy in Africa: Brazil's role in Guinea-Bissau. Africa Review, v. 5, n. 2, p. 104-117, 2013. Disponível em: https://doi.org/10.1080/09744053.2013.855356. Acesso at: 6 May. 2021.

ABDENUR, Adriana Erthal; DA FONSECA, João Moura Estevão Marques. The North's Growing Role in South-South Cooperation: keeping the foothold. Third World Quarterly, v. 34, n. 8, p. 1475-1491, 2013. Disponível em: https://doi.org/10.1080/01436597.2013.831579. Acesso at: 12 Jul. 2021.

ADETULA,Victor; BEREKETEAB Redie; OBI, Cyril. Introduction Regional economic communities and peacebuilding in West Africa and the Horn of Africa Regional in ADETULA, Victor; BEREKETEAB Redie; OBI, Cyril.Economic communities and peacebuilding in Africa: lessons from ECOWAS and IGAD. Abingdon, Oxon; New York, N.Y.: Routledge, 2021.

BANGURA, Ibrahim. Regional Trade and Security Cooperation: A Case Study of the Economic Community of West African States (ECOWAS). The Governance, Security and Development Nexus, p. 133-150, 2020. Disponível em: https://doi.org/10.1007/978-3030-49348-6_7. Acesso at:10 May 2021.

BERNAL-MEZA, Raúl. Contemporary Latin American thinking on International Relations: theoretical, conceptual and methodological contributions. Revista Brasileira de Política Internacional, v. 59, n. 1, 2016. Disponível em: https://doi.org/10.1590/00347329201600105. Acesso at:12 Jul. 2021.

BRAZIL AFRICA INSTITUTE. Commercial Diplomacy: The Brazilian Path to the African Market. IBRAF, Policy Brief n. 1, 2021. Disponível em: https://ibraf.org/wp-content/uploads/2021/08/Policy-Brief-EG.pdf. Acesso at: 5 Aug. 2021.

BULLARD, Nicolas. Global South, the Concept of in Encyclopedia of Global Studies, edited by JUERGENSMEYER, Mark and ANHEIER, Helmut K. Thousand Oaks, CA: Sage Publications, 2012. Acesso at: $30 \mathrm{Jul}$. 2021.

CABRAL, Lídia et al. Brazil-Africa Agricultural Cooperation Encounters: Drivers, Narratives and Imaginaries of Africa and Development. IDS Bulletin, v. 44,n. 4, p. 53-68, 2013. Disponível em: https://doi.org/10.1111/1759-5436.12042. Acesso at: 9 May 2021.

CLAY, Karen. South-South Cooperation as an Alternative Development Strategy: Rethinking Development Cooperation through South South Cooperation in Latin America and the Caribbean- Brazil and Haiti. FIU Electronic Theses and Dissertations, 2017. Disponível em: https://doi.org/10.25148/etd.FIDC001763. Acesso at: $28 \mathrm{Jul} .2021$.

DE RENZIO, Paolo; SEIFERT, Jurek. South-South cooperation and the future of development assistance: mapping actors and options. Third World Quarterly, v. 35, n. 10, p. 1860-1875, 2014. Disponível em: https://doi.org/10.1080/01436597.2014.971603.

ECOWAS. Commission Regional EUROTRACE Base.

ECOWAS. Decision A/DEC.5/01/03 relating to the adoption of Plan of Action to Facilitate Sub-Regional integration of Education objectives Pursunt to Sustainable Development, ECOWAS Official Journal Volume 42, 2003.

ECOWAS. Directive A/DIR.1/06/12 on Science, Technology and Innovation, 2012.

ECOWAS. ECOWAS Industrial Policy, ECOWAS Official Journal Volume 57, 2010.

ECOWAS. ECOWAS Revised Treaty, 1993.

ECOWAS. ECOWAS Treaty, 1975.

ECOWAS. ECOWAS Trade Information System (ECOTIS). Disponível em: https://ecotis.projects.ecowas.int/.

ECOWAS. ECOWAS member State to host 4th FEAFRO| Economic Community of West African States (ECOWAS), 2017. Disponível em: https://www.ecowas.int/ecowas-memeber-state-to-host-4th-feafro/.Acesso at: 6 Aug. 2021.

ECOWAS. Final Communique, ECOWAS Official Journal Volume 58, 2011.

ECOWAS. Regional Research Policy, 2012.

ECOWAS. Regulation C/REG.5/05/08 adopting ECOWAS Action Plan for the Development of Biotechnology and Biosafety, 2008. ECOWAS. Regulation C/REG14/06/13 on Small-scale hydropower program, 2013. 
ECOWAS. Supplementary Protocol A/SP.1/06/06 amending the Revised ECOWAS Treaty, 2006.

EREGHA, P. B. Foreign Direct Investment Inflow, Volatility, and Domestic Investment in West Africa. The Journal of Developing Areas, v. 49, n. 2, p. 273-294, 2015. Disponível em: https://doi.org/10.1353/jda.2015.0018. Acesso at: 26 Apr. 2021.

GOSOVIC, Branislav. The resurgence of South-South cooperation. Third World Quarterly, v. 37, n. 4,p. 733-743, 2016. Disponível em: https://doi.org/10.1080/01436597.2015.1127155.

GRAY, Kevin; GILLS, Barry K. South-South cooperation and the rise of the Global South. Third World Quarterly, v. 37, n. 4, p. 557-574, 2016. Disponível em: https://doi.org/10.1080/01436597.2015.1128817. Acesso at: 17 Apr. 2021.

GULATI, Ashok; DAS, Sandip. India-Africa Partnership in Trade and Investment:With Focus on the Agriculture and Food Sector. SSRN Electronic Journal, 2020. Disponível em: https://doi.org/10.2139/ssrn.3680833.

HACKENESCH, Christine; JANUS, Heiner. Post-2015: How Emerging Economies Shape the Relevance of a New Agenda. Rochester, NY, 2013. Disponível em: https://papers.ssrn.com/sol3/papers.cfm?abstract_id=2494824. Acesso at: 02 May 2021.

HARSCH, Ernest. Brazil repaying its “debt” to Africa. 2004. Disponível em: https://www.un.org/africarenewal/magazine/january 2004/brazil-repaying-its-debt-africa. Acesso at: 2 Aug. 2021.

HOLLINGER, Frank; STAATZ, John. Agricultural Growth in West Africa. Rome : 2015. Disponível em: https:/www.afdb.org/fileadmin/uploads/afdb/Documents/Publications/Agricultural_Growth_in_West_Africa_„Market_and_policy_drivers_-_OSAN.pdf.

KARAKI, Karim; VERHAEGHE, Elke. Understanding ECOWAS Trade Policy and Trade Facilitation Advancing Economic Integration One Hurdle at a Time. ECDPM, 2017. Disponível em: https://ecdpm.org/pedro-background-papers/. Acesso at: 11 Jul. 2021.

LAL, Rattan. Promoting “4 Per Thousand” and "Adapting African Agriculture” by south-south cooperation: Conservation agriculture and sustainable intensification. Soil and Tillage Research, v. 188, p. 27-34, 2019. Disponível em: https://doi.org/10.1016/j.still.2017.12.015. Acesso at: 23 Apr. 2021.

LECHINI, Gladys; DUSSORT, María. RIS South-South Cooperation: Latin American Theoretical Approaches. New Delhi, India: Research and Information System for Developing Countries, 2020. Acesso at: 5 Aug. 2021.

LEITE, Iara Costa; POMEROY, Melissa; SUYAMA, Bianca. Brazilian South-South Development Cooperation: The Case of the Ministry of Social Development in Africa. Journal of International Development, v. 27, n. 8, p. 1446-1461, 2015. Disponível em: https://doi.org/10.1002/jid.3191.

MAYAKI, Harouna. ECOWAS seeks the cooperation of development partners in addressing infrastructural deficits | Economic Community of West African States (ECOWAS). 2017. Disponível em: https://www.ecowas.int/ecowas-seeks-the-cooperation-ofdevelopment-partners-in-addressing-infrastructural-deficits.

MISHRA, Abhishek. Assessing Indian investments in West Africa. 2019. Disponível em: https://www.orfonline.org/expertspeak/assessing-indian-investments-in-west-africa-48768/.

MOHANTY, S. K; Dash, Priyadarshi. Trade and investment prospects of the IOR-ARC in the new millennium: New economic frontiers of the region. Research and Information System for Developing Countries, 2012.

RÖNNBÄCK, Ann-Sofi. ECOWAS and West Africa's Future: Problems or possibilities? 2018. Disponível em: https://www.divaportal.org/smash/record.jsf?pid=diva2\%3A141533\&dswid=8321.

VAZQUEZ, Karin; LUCEY, Amanda. Advancing South-South cooperation in education and skills development: lessons from the field. Jgu.edu.in, 2016. Disponível em: https://doi.org/http://hdl.handle.net/10739/1004.

Authors' Contributor Roles 